\title{
Power and Urban Life: Reading the Historical Changes of Tehran Before and After the 1979 Revolution From the Perspective of Ibn Khaldun's Theory*
}

\section{Iktidar ve Şehir Yaşamı: Tahran'daki Tarihsel Değişimi 1979 Devriminden Sonra Ibn Haldun Teorisi Perspektifinden Okumak}

\author{
(iD) Mahmoud Farhadimahali (1), (D) Masoumeh Nasiripourkalayeh (2) \\ (1), Allame Amini University, Iran, (2)Kharazmi University, Iran \\ (1)mahmoud_farhadi@yahoo.com, (2)m.nasiry21@gmail.com
}

Received: June 5, 2019

Accepted: November 13, 2019

Published: January 15, 2020

\begin{abstract}
How to explain the decline of cities? In response to this question, Ibn Khaldun has presented a broad theory that seems to be still functional after several centuries. In this paper, we aim to explain the history of Tehran before and after of 1979 Islamic Revolution with Ibn Khaldun's theory the history. The method of article is historical study and historical documents (newspapers, newsletters and other authentic historical sources) and books related to the city of Tehran have been cited as the main sources in this regard. The result of this study shows that if, based on the division of Ibn Khaldun, we consider five main courses for Tehran, in both historical periods (before and after the 1979 revolution), the city witnessed the passage of these stages. In the pre-revolutionary period, Tehran, with the presence of the Allies, and the coronation of Mohammad Reza Shah Pahlavi began their new era. With the coup d'état of 1954, the autocracy began in this city. the flourishing of intellectuals, the oil revenues in the $50 \mathrm{~s}$, the invasion of the labors to suburban and the Islamic revolution are the four phases in the fall of city ,respectively. With the victory of the Islamic Revolution and the burning of nightclubs, the era of victory began. Expansion of Islamic values and post-war reconstruction can be considered as the peak of power but Environmental crises and the problems caused by the immense growth of the urban population are greatest issues that the city faces during its decline. So these changes are explained using Khaldunian ideas in the area of government, city and power.
\end{abstract}

Keywords: Ibn Khaldun, Power, City, Asabiyyah, 1979 Islamic Revolution.

ORC-ID: M. Farhadimahali 0000-0002-7411-4612; M. Nasiripourkalayeh 0000-0001-6382-6211 "This article is a review of the paper presented at the "5th International Ibn Khaldun Symposium" organized on 27-28 April 2019 in Istanbul. 
Öz: Kentlerin çöküşü nasıl açıklanır? Bu soruya yanıt olarak ibn Haldun, birkaç yüzyıl sonra bile hala işlevsel görünmekte olan geniş bir teori sunmaktadır. Bu yazıda, 1979 islam Devrimi'nden öncesi ve sonrasındaki dönemlerdeki Tahran tarihinin ibn Haldun'un teorisiyle açıklanması amaçlanmıştır. Makalenin yöntemi, tarihsel çalışmadır ve bu bağlamda tarihi belgeler (gazeteler, bültenler ve diğer otantik tarihi kaynaklar) ve Tahran ile ilgili kitaplar, ana kaynaklar olarak belirtilmiştir. Ibn Haldun'un bölümlerine dayanarak, bu çalışmanın sonucu, Tahran için her iki tarihsel dönemdeki (1979 devriminden önce ve sonra), beş ana dersi ele aldığımızda, şehrin bu aşamaların geçişine tanıklık ettiğini göstermektedir. Devrim öncesi dönemde, Tahran'da müttefiklerin varlığı ve Muhammed Rıza Şah Pehlevi'nin taç giymesiyle yeni bir çağ başlamış, 1954 darbesi ile de şehirde otokrasi başlamıştır. Entelektüellerin gelişmesi, 50'li yıllarda petrol gelirleri, işçilerin banliyölere akını ve Islam devrimi kentin düşüşündeki ayrı ayrı dört aşama olarak yer almaktadır. Islam Devrimi'nin zaferi ve gece kulüplerinin yakılmasıyla, zafer çağı başlamıştır. Islami değerlerin genişlemesi ve savaş sonrası yeniden yapılanma, iktidarın zirvesi olarak değerlendirilebilir, ancak çevresel krizler ve kentsel nüfusun muazzam büyümesinden kaynaklanan sorunlar, kentin düşüşü sırasında karşılaştığı en büyük sorunlardır. Dolayısıyla bu değişimler ibn Haldun'un hükümet, kent ve iktidar alanındaki fikirleri kullanılarak açıklanmaktadır.

Anahtar Kelimeler: Ibn Haldun, Iktidar, Şehir, Asabiyyah, 1979 Islam Devrimi

\section{Introduction}

How do cities survive growth and decline cycles? This question has occupied many minds for years and many have sought to answer the question so that they can explain the relation between power and city life. Ibn Khaldun is one of the thinkers who have done theoretical work in this field .In order to explain the growth and decline cycles, he has presented a kind of linear evolutionary theory that, although it has been criticized, appears to have proper capabilities for explaining some of the characteristics of the Third World countries, especially the Middle East. According to Ibn Khaldun, all human societies have common ground in spite of the cultural, social and historical differences and diversities, so that the principles and components can be generalized to all human beings and communities. Though Ibn Khaldun's Cyclical Theory has been variously applied to the study of some Muslim Empires and cities especially of the Middle East origin; Umayyad, Abassid, Saffavid, Seljuk, and those of Central and Southeast Asia like, Mughal, Aurangzeb, Qutub Shahi, Aceh and Malaka (Hitti 1970; Itzkowit 1972; Lipidus 1991; Ishak 2000; Lindholm 2002; Oloruntimehin 1972; Ahmad 2003) it has not been done (not to the knowledge of these scholars) to the Tehran, the capital of Iran. In this article we will try to study the history of Tehran before and after the Islamic Revolution in 1979, in light of Ibn Khaldun's theory of Transformation and political governance, to determine the extent to which this theory can explain these changes. 


\section{Cyclical Evolutionary Theory of Ibn Khaldun}

Ibn Khaldun adopted a systematic approach to the study of society which he called IIm Al Imran, the "science of culture and society". The work has several aspects to its expositions. However, the concern of this research work is the area that espouses on the span of governance and city life.

To Ibn Khaldun political administration lasts for four generations before it is overthrown or supplanted and replaced by a new one, which replenish and then, follow the same process to apogee and then, collapse. At rise and growth, rulership is held together and united by what he called asabiyyah broadly translated as "groupfeeling/solidarity" which is the fundamental building block which provides strength to the successful origins and development of a fledgling empire or polity. "Asabiyyah" is a rich term which encompasses a range of meanings - authors have generally translated it through particular expressions of universal sociological notions such as "public spirit", "social solidarity", "group cohesion", "espirit de corps'”.( Lacoste, 1984: 110). Erwin Rosenthal describes it as "the motor development of the state (Ibid, 109), whilst Toynbee posits 'Asabiyyah as the "basic protoplasm all bodies politic and bodies social are built up".(Ibid, 110).

The central thesis of Ibn Khaldun then is that a ruler unites his virile Bedouin people with a common feeling of 'Asabiyyah and often comes to power by overturning an existing established civilization which has reached the end of its life-cycle, reveling in decadence and luxury. The whole conception of historical development is based upon these two dichotomous groups: the nomadic and sedentary (Lacoste, 1984: 94).This was witnessed with the rise of the first Islamic Caliphate, from its humble desert origins, defeating the Roman and Persian Empires.

Due to solidarity and cultural togetherness, the group takes control of governance; administer justice and as time went by, the controlling group living a luxury and opulence of urbanization and sedentalization are also overthrown by fresher tribesmen, who soon became urbanized and are also overthrown by fresher tribesmen (Ibn Khaldun 1981:313). To Ibn Khaldun, the cyclical pattern marks the Islamic political history. In essence, social group came together to organize themselves and take over governance through violence. In power, the rulership group institute good leadership, organized egalitarian economic system, fortified themselves by social reorientation, variables and functional political activities. Soon afterwards, the social cohesion began 
to drift, dwindle and visibly decay as individualism, greed, avarice, corruption and sleazebag cropped in the system of government.

This is so because, the rulers due to foundational derailment, after several generations began to seek, according to Ibn Khaldun "the help of clients and followers against men of his people" in order to sustain themselves in governance. The gradual disenfranchisement of his kinsmen occurs because the ruler fears that they, as co- equals and tribal brothers, can and will make claims on his sovereignty. In response, he slowly replaces them with slaves, clients and hired employees who are directly reliant on him for their positions. The ruler's aim is to increase his authority by exchanging his potential rivals for a convoy of dependants. Despite its advantages to the rulers, Ibn Khaldun, argues that the eventual effect of the systematic downgrading of one's kin and close tribal allies in favour of dependant clients is negative. The ruler does gain more leeway, in Charles Lindholm's words, for exercising his own autocratic authority dispensing with those who had helped his ancestors' to victory (Lindholm: 51). But according to Ibn Khaldun, without these kinsmen and allies to his own to support him, he is instead surrounded with flatterers and sycophants, and can be easily ousted by more aggressive and unified tribal opponents invading his realm from the periphery. This is understandable because clients, hangers-on and slaves lack the essential ingredient that promotes social solidarity and self sacrifice; this ingredient is to Ibn Khaldun, the asabiyyah, group feelings. Leadership becomes authoritarian and viciously tyrannical. They employ coercion and threat to extract the people's loyalty. The consequences of this are many. Qualities of administration begin to erode until the regime meets its waterloo and subsequently eased out by another group of rulership. These processes of rise, growth and fall to Ibn Khaldun continue in a cyclical manner. Before, during and after Ibn Khaldun's theory, empires, kingdom, caliphates, sultanates, etc, have risen and fallen following the pattern enunciated by Ibn Khaldun. This was the story of Abbasid and Umayyad caliphates, Seljuk, Saffavid and Mughal kingdoms in one way or the other.Scholars who criticized Ibn Khaldun can be classified in to three groups. The first are made up of those who think Ibn Khaldun was too simplistic in looking at the history of Muslim states within small span of just four generations.

Many polities like Ottoman, Saffavid and Mughal according to this school survived beyond four generations specified by Ibn Khaldun. Indeed, the Ottoman lived between 13th and 20th Centuries. The defense here is that Ibn Khaldun's mentioning of four generations is allegorical and not categorical. In this vein therefore, the import of Ibn Khaldun's theory to this study is that whatever the extent of growth and span of an 
empire or a political authority, it shall decline and collapse. The second category charged that Ibn Khaldun did not apply enough moral and adequate faith-based gauges in his theory. To this group, what should be upper most in the rise and fall of any Islamic polity is that the "fresher" coming from the periphery are motivated by the zeal to return Islam and Society to the Caliphate style as witnessed during the era of the rightly guided Caliphs who succeeded the Prophet(SAW). However it should not be lost here that whatever the reason for a fresh overthrown, the fact of social feelings as expounded by Ibn Khaldun cannot be discountenanced. It also meant that whatever the social order that motivated the takeover depend entirely on the inspiring ideology, philosophy and social form. Except in few cases, most "fresher" are motivated by group interest and solidarity feeling to seek power and wealth (Lapidus 1991:207; Lindholm 2002:59). The third group contains those who felt that the cyclical theory is no longer applicable to the modern highly developed and organized world. To this category of Thinkers, there are no longer Bedouins with uncivilized characteristics uncouthness and insubordination. Even if they exist, they no longer have access to the cities which are now developed, fortified and transformed by technology. In addition, complex nation states, civic responsibilities and nationhood system have been evolved which render constant rise, fall and collapse mechanisms in nullity. Nations are now defined by inviolable borders and national institutions, organs and imperatives. In essence, to this group, Ibn Khaldun never foresaw that development in government, security, military and structuralized economy will erode tribal feelings and thereby eliminate cyclical theory (Ahmad2003:71). In as much as all these are obvious developments that have questioned the veracity of Ibn Khaldun theory, they do not in themselves repudiate the complete correctness of the theory. A modern re interpretation of the cyclical theory would construe the phrase "rise" and "fall" from dynamic perspectives. Rise may not necessarily continuously mean the physical creation or evolvement and growth of a particular state. In the contemporary sense, rise should mean, playing the centre-stage role; dominating the global scenes, and directing international thinking and actions. In the same vein, decline, fall or collapse mean inability to play a frontline role in the global equation of power (Okene \& Ahmad, 2011: 82-84). If these re interpretations are latent, it means therefore that the Ibn Khaldun theory is still valid. Indeed, this is the position of this work.

\section{Method}

The method of article is historical study and historical documents (newspapers, newsletters and other authentic historical sources) and books related to the city of Tehran have been cited as the main sources in this regard. The data collection tool was 
reversed questionnaire and researchers have tried to collect evidence from various historical periods, while investigating the history of Tehran in historical sources, provide tools for testing the theory of Ibn Khaldun.

\section{Findings}

\subsection{Tehran before 1979 Islamic Revolution}

Tehran was elected to the capital of Iran at the beginning of the thirteenth century, and from that time on, Tehran was called the Darul-Khalafeh (meaning the capital). In the pre-revolutionary period, Tehran, with the presence of the Allies and the coronation of Mohammad Reza Shah Pahlavi, began his new era. Certainly, radical changes have been made in Tehran since 1920, which is divided into four distinct periods. From 1920 to 1942, after which the gutters and gates were destroyed, the city expanded from four directions and found some regular and geometric shapes. Also, buildings and facilities of the National Bank (including the National Bank of Iran Fund), the Ministry of Foreign Affairs, the country's commander-in-chief, the railway station, the University of Tehran, Tehran Radio Transmitter Station, the Club of Officers and several hospitals related to this course. In this period from, following Tehran city politics, the city of Tehran has cultural facilities such as the Culture Hall, cinemas and active theaters, and light cafes and restaurants and small hotels in the streets of Lalehzar, Shahabad, Shahr Reza and Pahlavi streets, including two enclosures A great amusement park next to the Mayor's Guesthouse with a variety of games and amusement arcades and open-air cinema called City Hall Café, as well as another entertainment area called boot clubs with a large lake swimming pool, which was a sailing and submarine hangar, with a variety of entertainment halls And a place to move The electric cars on Pahlavi Street were among the most attractive places to spend their leisure time

Between 1942 and 1954, which was at the same time as World War II, there were no significant changes in the country due to the consequences of the World War and political problems.

During 1954 to 1979, the city of Tehran rapidly expanded and modern buildings newly constructed townships and alleys (boulevards) were to be built, a large urban complex called Shahrestan Pahlavi was to be built in Tehran's Abbasabad hills in this year. A total of high-rise buildings and towers, such as the Lion and Sun Tower, were to be built and, after construction, could be turned into the largest and most advanced in Asia. The advancement of Tehran technology was that foreign tourists called Tehran the Tokyo II Asia, in 1977 Tehran was unveiled as the 11 th most advanced city in 
terms of building and modern technology. According to the statistics of the year 1355 , the population of the city amounted to $4,350,000$.

To illustrate the extent of urbanization in Tehran, we can refer to the various photographs of that era. In pictures 1 and 2, Tehran's image has been shown in the space of thirty years (from 1946 to 1976). The volume of traffic and the change in the manner of coverage, along with various signs of urban life, show how extensive
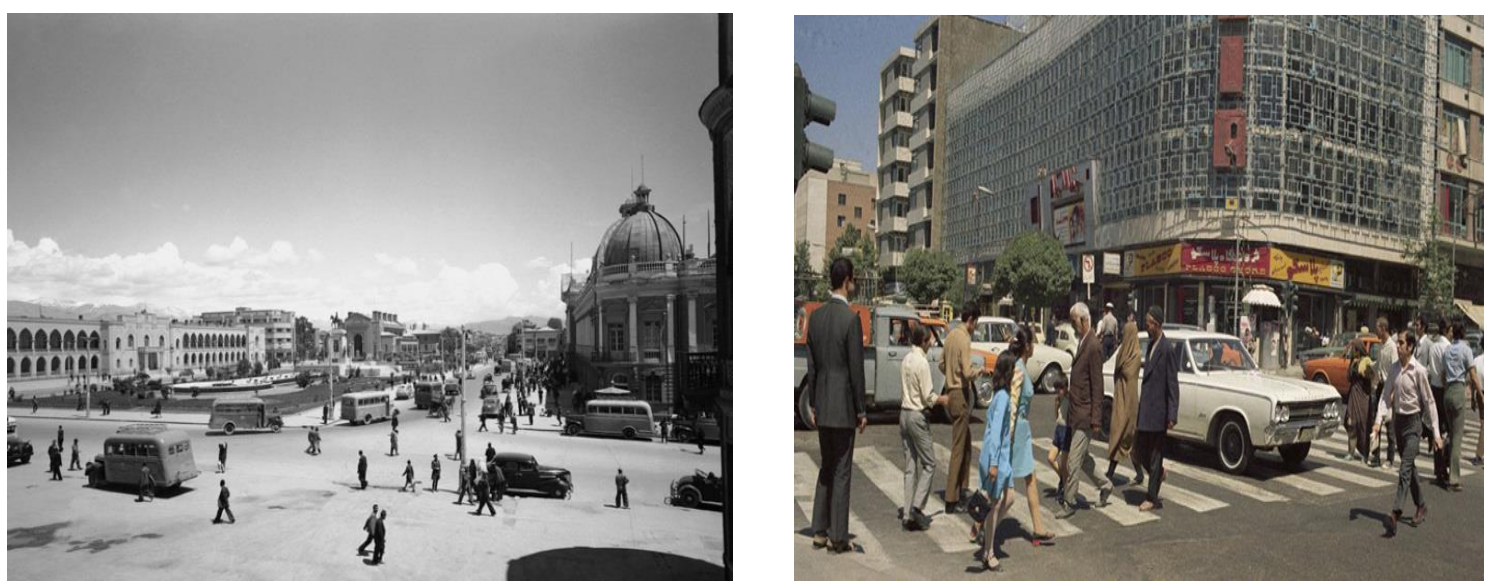

Tehran's changes have been in these three decades.

Picture 1. Tehran, 1946

picture 2. Tehran, 1976

(Source: Business insider, 2019).

This growth, which was accompanied by the expansion of large and small industries in the outskirts of Tehran and the exorbitant growth of the body of the state system, sent migrant populations to Tehran, the immigrants who, despite the empty tissues inside the city, had the power and financial power .there were no residences in them. The onset of the outbreak of marginalization in the suburbs of Tehran and the outbreak of some urban intrusions occurred when residential towers were built on the periphery of the city's central axis. Immigrants, with the purchase or occupation of small plots and gradual growth, created limited, but dispersed neighborhoods on the margins of the external communication axes such as Karaj Road, Khorasan Road, Damavand Road and Saveh Road, and, by recruiting services, equipment and facilities The city provided its permanent housing equipment in these areas (which now constitute the satellite towns of Tehran), including the city of Karaj and its suburbs, the white ground and Islamshahr. The demands of this disadvantaged class became very effective in the years to come, especially at the beginning of the revolution, in consolidating marginal settlements and changing the city of Tehran. 


\subsection{Tehran after the 1979 Islamic Revolution}

As noted, the unbalanced development of Mohammad Reza Shah Pahlavi caused a large marginal population to invade the border of Tehran. The imbalance between political space and cultural space has led various forces to cooperate to overthrow the Pahlavi regime. Eventually, in 1979, the Pahlavi regime collapsed and the revolutionaries took control of the government. For the analysis of this era in the language of Ibn Khaldun it can be said that a group with a more powerful asabiyyah could defeat the Pahlavi regime, which no longer had a powerful asabiyyah of the past. The plans of Mohammad Reza Shah Pahlavi's period were almost stopped by Iran's 1979 revolution And Tehran's Mayor Nikpay, for the sake of cooperation with Western colonialism, Disability to solve the traffic scourge, the massive bribes during the responsibility, the large amount of corruption, the transfer of government bids to individuals for personal gain, the change of Tehran's master plan, the creation of a market for the sale of foreign tools and machines And to prevent the national bourgeoisie and to reduce national production and ... was sentenced to death and executed on April 22, 1979. The conquest of Tehran was accompanied by the rule of Islamic rulings, in such a way that Shahr-e -no was burned down as a symbol of prostitution and corruption by the revolutionary forces. This era can be called a victory period. During this period, the most important Islamic law was laid the foundations of the Islamic Tehran. Examples such as the burning of Shahr-e-no and the collection of alcoholic beverages and the closing of gambling houses, along with much other evidence, show that revolutionaries in this period tried to implement their principles and laws in the city. pics 3 and 4 show the most important signs of this era.
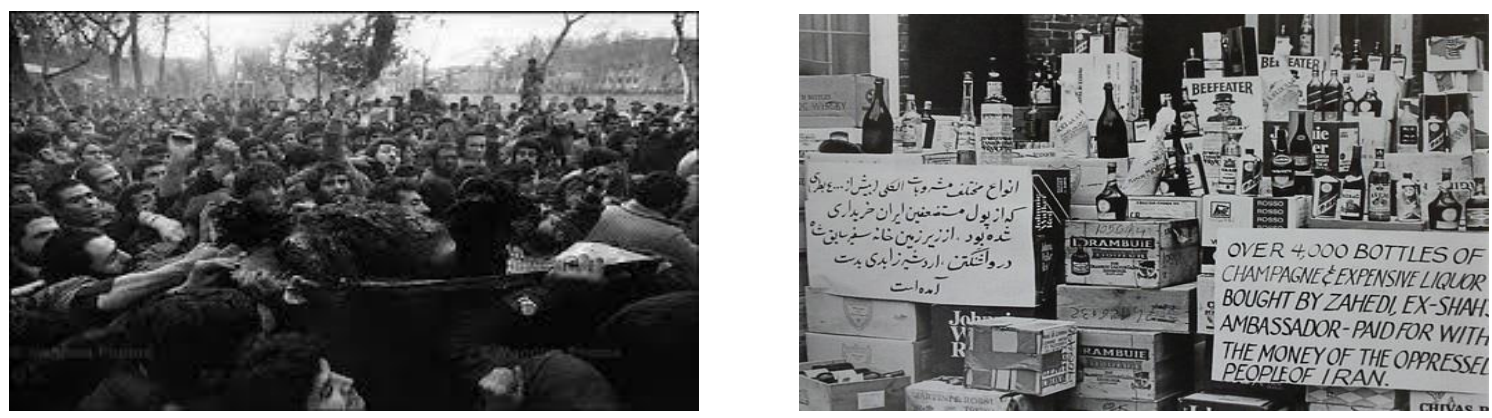

Picture 3. burning Shahr-e-; burned corpse of a prostitute on the hands of the revolutionaries Picture 4. Collect alcoholic beverages from the city of Tehran and homes

With the start of the war between Iran and Iraq, the development plan of Tehran was also in trouble. In the last years of the war, Tehran witnessed a missile bombardment, which raised the need for reconstruction for this city more seriously than ever. The 
invasion of war-torn people from the southern parts of Iran to Tehran has increased the population of Tehran. In the meantime, everything that is not on the path to the ideology of the revolution comes out of the process of experience. The street whose name has been changed or the cinema that is closed is examples of the cleaned spaces after the 1979 Iranian Revolution. The division of cities by the Ministry of the Interior into two types of migratory and clandestine climates fueled the structural divide between cities and provided more grounds for the economic prosperity of Tehran in the following years. In these years a group seized Tehran with the seizure of seized land by the revolutionary regime. By issuing a decree establishing the Housing Foundation and the 100 account, the new government placed housing for the poor on top of its plans and provided the groundwork for fulfilling one of the demands of the revolution. Housing production peaked in the years 1979 and 1980. On the other hand, due to ideological differences with the previous government, the revolution coincided with the abolition of any urban execution plan, such as comprehensive plans and a system of boundaries. The revolutionary government looked at these plans in the form of an affiliated and accepted pattern of the West, and by the end of the year 1979, when it returned to the Ministry of Housing and Urban Development, there were no plans for the city. By disregarding the criteria for the development of Tehran, the extravagance growth in all directions of the city continued to increase, and with the continuation of revolutionary plans, migration to the regions around Tehran increased.

After the war between Iran and Iraq, the new organization of Tehran during the period of construction - with the introduction of the concept of development into the sociopolitical space of Iran and the subsequent construction of highways and parks - once again made the development of urban spaces. The effort to create a modern city was centered on work. Tehran Metro Construction started in 1365 and is still unfinished. With the growth of urban structures, for example, highways, which were actually built to create communication routes between different neighborhoods, once again challenged the separation of space and class in Tehran. In the early 2000s, questions such as urban life and civil life were raised about Tehran. Establishing cultural corridors and reviewing the map of parks were among the measures that tried to improve urban life. But, in general, all of these plans could not significantly increase social exposure due to one-sided participation and planning.

Due to these changes in power patterns, Tehran has faced numerous pollution and environmental problems in the last decade. Today's issues in Tehran include the financial crisis of the municipality and the lack of a stable and secure income, excessive migration, inadequate public transport, social crises, the existence of 550 
worn out schools and 67,000 salaried employees in the municipality, urban decay and children's work and sleeping packs (Irna, 2019).

Table 1. Tehran History Cycle

\begin{tabular}{|l|l|l|}
\hline History cycle & \multicolumn{1}{|c|}{ Before Revolution } & \multicolumn{1}{c|}{ After Revolution } \\
\hline Conquer & $\begin{array}{l}\text { Coronation of Mohammad Reza Shah } \\
\text { Pahlavi }\end{array}$ & $\begin{array}{l}\text { Burning Shahr-e-no / Destroying } \\
\text { Gamblers and Nightclubs }\end{array}$ \\
\hline Autocracy & The coup d'état of 1954 & $\begin{array}{l}\text { Expansion of Islamic values / anti- } \\
\text { Semitism }\end{array}$ \\
\hline Peak power & $\begin{array}{l}\text { Cultural flourishing and urban } \\
\text { development }\end{array}$ & Post-war reconstruction \\
\hline Degeneration & $\begin{array}{l}\text { The 70s and the injection of oil money } \\
\text { into the market }\end{array}$ & $\begin{array}{l}\text { Sanctions and postponement of urban } \\
\text { development }\end{array}$ \\
\hline Fall & $\begin{array}{l}\text { The invasion of the margins and } \\
\text { revolution }\end{array}$ & Reproduction of urban problems \\
\hline
\end{tabular}

\section{Conclusion}

The initiation of policies and strategies for modern urbanization in Iran can be traced back to the Pahlavi era, whereby the construction of architecture and urban spaces sped up a lot. This process of production of space was also influenced by Reza Khani's policies for aligning the land and the establishment of a single nationality, and in line with the world of architecture and urban planning. In this way, the space experience in the city of indigenous elements, which was formed by the architectural interiors, was emptied, and proceeded to a similar experience in different cities. Today's urban spaces in Iran, more than anything else, represent a blur of uncertainty. From the Greek decoration cartoon and the inspiration from the ancient aristocratic palaces, to the scattered hills, all together-together they form a cluster called the city. With the advent of the revolution, as a collective experience, urban spaces became the bedrock for the formation of social movements. The dialectic of people and urban space extends from writings on walls and leaflets to their presence on the street. After the revolution, without the passing of the day, the city is confronted with the destruction and change of many spaces. In the meantime, everything that is not on the path to the ideology of the revolution comes out of the process of experience.

The mind tries, in the face of such spaces, to link experience in a historical relation to the past and present. Memory and experience in this empty space mix. Not that the surplus of the revolution has added to the city and, incidentally, here it has diminished and erased something. 
The experience of confronting empty spaces can be seen again in the years after the war. Urban plans in these years have been trying to quickly change the face of Tehran and considered the development of hasty. But this time, this purification was not about destruction, but on the contrary, with the construction and filling of ruined ruins and rubble. Creatures every day looked more and more like each other from the city and added to the space. The experience of the area with a good approximation of the daily relations of the residents of Tehran has been eliminated and with the spread of consumerism limited to chain stores and shopping centers. The streets make sense of the inside of the car for the cavalry, and the footpaths float away from the city; a fragmentary experience of the city resulting from the slip of urban spaces. In this crisis of civilization and with the dominance of quality, citizens of the city, which are no longer inhabitants, search for their concept of life instead of public realms in private realms. Today's urban spaces in Iran, more than anything else, represent a blur of uncertainty. From the Greek decoration caricature and the inspiration from the ancient aristocratic palaces, to the scattered hills, all together-together they form a cluster called the city

The comparative study of the latest Mayor's interview at the time of Pahlavi and a member of the Tehran City Council in 2019 shows that Tehran's problems are exactly the same. So that today's problems can be repeated in the same way as previous problems. This is a sign of confirmation of Ibn Khaldun's cyclical theory. Tehran, as an example of a third-world metropolis, seems to have been plunged into a circle from peak to downfall, as Ibn Khaldun's foresight predicted. In terms of Ibn Khaldun's theory, Tehran is a city which its Assabiyah has reduced and is in danger of collapse. The city faces many problems, and participation of citizens is a way to solve problems but the lack of social solidarity and inefficient management has delayed the resolution of these issues. The lack of social solidarity and inefficient management are two of the concepts that Ibn Khaldun referred to in his ideas centuries ago, and attached the social bias of cities to these two concepts.

\section{References}

Alatas, J.F.(2008) "Islam and Civilization in the Writings of Abd al-Rahman Ibn Khaldun" in IAIS Journal of Civilization Studies, Vol 1 No 1 October 2008, pp.66-86

Ali Çaksu, "Ibn Khaldun and Hegel on Causality in History: Aristotelian Legacy Reconsidered." Asian Journal of Social Science 35, no. 1 (2007): 79.

Alkali, M.N. (2006) "Elkanemi's Response to the Extension of Shaykh Uthman Dan Fodio's Jihad Against Borno" in Bobboyi, H. and Yakubu, A.M....pp.231-239 
Augi, A.R.(1984) "The Gobir Factor in the Social and Political History of the Rima Basin", PhD Thesis, Ahmadu Bello University, Zaria, Nigeria

Boyd, Jean (2006) “The Role ofEducated Women in the Sokoto Caliphate: Nana Asma'u, 1793 1864" in Bobboyi, H and Yakubu, A.M... pp.124-133

Bruce B. Lawrence, "Introduction: Ibn Khaldun and Islamic Ideology," in Ibn Khaldun and Is/amic Ideology, ed. Bruce B. Lawrence (Leiden: E.J. Brill, 1984), 8.

Cornell Fleischer, "Royal Authority, Dynastic Cyclism, and “Ibn Khaldunism" in SixteenthCentury Ottoman Letters," in Ibn Khaldun and Islamic Ideology, ed. Bruce B. Lawrence (Leiden: E.J. Brill, 1984)

H. A. R. Gibb, "The Islamic Background of Ibn Khaldūn's Political Theory." Bulletin of the School of Oriental and African Studies 7, no. 1 (1933): 31, accessed October 1, 2015, doi: 10.1017 /S0041977X00105361.

Hamman, M. (2006) "Dynastic Conflicts and Political Instability in Muri Emirate, 1833-1898" in Bobboyi, H. and

Hayden V. White, "Ibn Khaldûn in World Philosophy of History." Comparative Studies in Society and History 2, no. 1 (1959): 112.

Hiskett, M. (1973), The Sword of Truth, London: Longman

History of Tehran Edit second edit Tehran: GIS Institute of Geography and Cartography, 2008. ISBN 978, 964, 342, 253, 0.

Hitti, P.K.(1970), History of the Arabs, London: Macmillam Press

Ibn Khaldun (1981) Al- Muqaddimah (Rosenthal translation), Beirut: Dar al Qalam

Ibn Khaldun, The Muqaddimah (Unabridged), trans. Franz Rosenthal, 55, accessed October 1, 2015, https://asadullahali.files.wordpress.com/2012/10/ibn_khaldun-al_muqaddimah.pdf.

Ige,J. (2006), "The Ideal of the Sokoto Caliphate in the Outlying Districts:The O-kun Factor in the British Conquest of Northern Nigeria, 1897-1906" in Bobboyi, H and Yakubu, A.M. (eds)...pp. 271-284

Ishak, M.S.A. and Ottman, M.R.(2000) The Malays in the Middle East, Kula Lumpur: Universiti Malaya

Itzkowit,Norman (1972) Ottoman Empire and Islamic Tradition, Chicago: University of Chicago Press

Kirk-Greene, H.M. (1965) The Principles of Native Administration in Nigeria: Selected Documents, 1900-1947,London: Longman

Lindholm, C.(2002), The Islamic Middle East Tradition and Change, UK: Blackwel Publishers Ltd Lipidus, I.M. (1991) A History of Islamic Society, Cambridge; Cambridge University Press

M. Abdul Qadir, "The Social and Political Ideas of Ibn Khaldun." The Indian Journal of Political Science 3, no. 2 (1941): 118.

Mahdi, Abdullahi (1985) "The Jihad and Its Role in Strenghtening the Sarauta (Kingship) System in Hausaland inthe 19th Century: The Case of Kano" in Ade Ajayi,J.F. \& Ikara, Bashir (eds) Evolution of Political Culture in Nigeria, Ibadan, Nigeria: University Press Ltd

Mahmoud Dhaouadi, "The Ibar: Lessons of Ibn Khaldun's Umran Mind." Contemporary Sociology 34, no. 6 (2005): 586. 
Nurullah Ardiç, "Genealogy or Asabiyya? Ibn Khaldun between Arab Nationalism and the Ottoman Caliphate," Journal of Near Eastern Studies 71, no. 2 (2012): 317.

Ronald A. Messier, "The Worlds of Ibn Khaldun: Introduction." The Journal of North African Studies 13, no. 3 (2008): 275, accessed October 1, 2015, 10.1080/13629380701844482.

Saeed, A.G. (2006) "The Sokoto Caliphate and Mahdism: The Clash at Danki Between Shaykh Hayat b. Sa'id and Lamido Zubairu, 1892" in Bobboyi, H. and Yakubu, A.M. (eds)...pp.160-186

Sani, A.B. (2006) "Trade and Diplomatic Relations Between the Sokoto Caliphate, Ghadames, Tuat and Abzin in the Nineteenth Century" in Bobboyi, H. and Yakubu, A.M. (eds)... pp.253-2270

Shea, P.J. (2006) "The Sokoto Caliphate and Economic Advantages of Size: Quality, Variety and Efficiency in the Textile Industry" in Bobboyi, H. and Yakubu, A.M. (eds)...pp. 133-148

Spahic, Omar (2005) "City Planning in Ibn Khaldun's Thought", Paper presented at the 8th Int'l Conference of the Asian Planning Schools Association at Universiti Sains Malaysia(USM), Penang, Malaysia, 11-14 September

Tukur, M. (1999) Leadership and Governance in Nigeria: The Relevance of Values, London: Ubah, C.N. (1985) Administration of Kano Emirate under the British, 1900-1930, Enugu: usuf M. Sidani. "Ibn Khaldun of North Africa: An AD 1377 Theory of Leadership." Journal of Management History 14, no. 1 (2008): 76.

Yolanda Gamarra, "Ibn Khaldun (1332-1406): A Precursor of Intercivilizational Discourse." 28, no. 3 (2015): 455, accessed October 1, 2015, doi: 10.1017/S0922156515000217.

Yves Lacoste, Ibn Khaldun: The Birth of History and The Past of the Third World (London: Verso, 1984) 